\title{
Frequent Shifts in Aspergillus flavus Populations Associated with Maize Production in Sonora, Mexico
}

\author{
A. Ortega-Beltran and P. J. Cotty†
}

First and second authors: School of Plant Sciences, and second author: United States Department of Agriculture-Agricultural Research Service, School of Plant Sciences, The University of Arizona, Tucson.

Current address of A. Ortega-Beltran: International Institute of Tropical Agriculture, PMB 5320, Oyo Road, Ibadan, Nigeria. Accepted for publication 10 October 2017.

\begin{abstract}
Aspergillus flavus frequently contaminates maize, a critical staple for billions of people, with aflatoxins. Diversity among A. flavus L morphotype populations associated with maize in Sonora, Mexico was assessed and, in total, 869 isolates from 83 fields were placed into 136 vegetative compatibility groups (VCGs) using nitrate-nonutilizing mutants. VCG diversity indices did not differ in four agroecosystems (AES) but diversity significantly differed among years. Frequencies of certain VCGs changed manyfold over single years in both multiple fields and multiple AES. Certain VCGs were highly frequent $(>1 \%)$ in 2006 but frequencies declined repeatedly in each of the two

subsequent years. Other VCGs that had low frequencies in 2006 increased in 2007 and subsequently declined. None of the VCGs were consistently associated with any AES. Fourteen VCGs were considered dominant in at least a single year. However, frequencies often varied significantly among years. Only $9 \%$ of VCGs were detected all 3 years whereas $66 \%$ were detected in only 1 year. Results suggest that the most realistic measurements of both genetic diversity and the frequency of A. flavus VCGs are obtained by sampling multiple locations in multiple years. Single-season sampling in many locations should not be substituted for sampling over multiple years.
\end{abstract}

Maize is cultivated throughout Mexico regardless of elevation, soil type, rainfall, and agroecosystem (AES) (Plasencia 2004; SIACON 2010) on approximately one-third of Mexico's cultivable land (Eakin et al. 2014). The majority of the caloric daily intake for over half of Mexico's population is provided by maize (FAO 2010). However, consumption of maize can expose populations to unhealthy aflatoxin concentrations (Battilani et al. 2016; Hua et al. 2016; Plasencia 2004).

Aflatoxins are highly toxic, naturally occurring mycotoxins produced by several members of Aspergillus section Flavi, which frequently contaminate maize, cottonseed, peanut, and tree nuts in warm agricultural areas (Bandyopadhyay et al. 2016; Cotty et al. 1994). Aflatoxin $B_{1}$, the most toxic and prevalent, is classified as a group 1a carcinogen by the International Agency for Research on Cancer (IARC) and is strictly regulated across the globe through legislation (Grace et al. 2015; IARC Working Group 2002; Wu 2015). These potent toxins can induce immune system suppression, growth retardation, hepatocellular carcinoma, and death in both humans and livestock (Hernandez-Vargas et al. 2015; Probst et al. 2007; Wu 2015).

Aspergillus flavus, the most common causal agent of contamination (Amaike and Keller 2011; Cotty et al. 1994), can be subdivided in the L and S morphotypes, which differ in morphological, physiological, and genetic criteria (Cotty 1989; Ehrlich et al. 2005). The $\mathrm{L}$ morphotype produces abundant conidia, fewer but larger sclerotia, and variable concentrations of B aflatoxins. The $\mathrm{S}$ morphotype produces fewer conidia, abundant small sclerotia, and, on average, high concentrations of B aflatoxins (Cotty 1989, 1994b; Probst et al. 2007). Both morphotypes are distributed

†Corresponding author: P. J. Cotty; E-mail: peter.cotty@ars.usda.gov

This study was funded by the United States Department of Agriculture (USDA) Foreign Agricultural Service, Scientific Cooperation Research Program, USDA Agricultural Research Project 5347-42000-02-00D, and CONACyT-Mexico (Scholarship 309103).

(C) 2018 The American Phytopathological Society worldwide over a great diversity of AES (Binder et al. 2007; Cotty and Mellon 2006; Jaime-Garcia and Cotty 2006; Probst et al. 2014).

Communities of aflatoxin-producing fungi are examined in order to identify the most common causal agents of contamination in a given area or cropping system (Boyd and Cotty 2001; Cardwell and Cotty 2002; Donner et al. 2009; Doster and Michailides 1994b; Ehrlich et al. 2007; Gao et al. 2007; Horn and Dorner 1999; Joffe 1969; Nesci and Etcheverry 2002; Ortega-Beltran et al. 2015; Probst et al. 2010). However, relatively few studies have examined intraspecies diversity of an aflatoxin producer across regions despite abundance of genetic diversity in relatively small areas, including individual fields (Atehnkeng et al. 2016; Bayman and Cotty 1991b; Horn et al. 1996; Mauro et al. 2013; Papa 1986; Pildain et al. 2004; Sweany et al. 2011). The state of Sonora in Mexico possesses diverse AES at elevations ranging from 0 to 2,100 $\mathrm{m}$ above sea level (MASL) over relatively short distances (Felger et al. 2001; INEGI 1988). Maize is cultivated in each of these AES (SIACON 2010) and A. flavus is associated with the maize (Ortega-Beltran et al. 2015). Knowledge of the genetic diversity within populations of aflatoxin-producing fungi resident in Sonora is needed in order to both more thoroughly determine the etiology of the state's aflatoxin contamination and optimize selection of widely distributed atoxigenic A. flavus genotypes for aflatoxin biological control products targeted to the examined region (Mehl et al. 2012).

Vegetative compatibility analyses (VCA) using nitrate-nonutilizing (nit) mutants are used to assign isolates into vegetative compatibility groups (VCGs) (Leslie 1993). The vegetative incompatibility system in the genus Aspergillus, as in other fungal genera such as Fusarium, Neurospora, and Verticillium, is regulated through several unlinked loci (Bayman and Cotty 1991b; Leslie 1993). During VCA, regions of prototrophy form between complementary mutants that are isogenic at heterokaryon incompatibility (het) loci controlling vegetative incompatibility. Such mutants, and the isolates from which they are derived, are said to belong to the same VCG (Bayman and Cotty 1991b; Leslie 1993; Papa 1986). In A. flavus, VCGs are clonal lineages and isolates within a VCG are more closely related to each other than to members of other VCGs (Bayman and Cotty 1991a; Grubisha and Cotty 2015; Mehl and Cotty 2010; 
Ortega-Beltran et al. 2016). Members of the same VCG share epidemiologic and physiologic characteristics, including aflatoxinproducing ability (Leslie 1993; Mehl and Cotty 2010, 2013).

Although VCGs are useful markers of species diversity, the labor required for VCA increases with quantities of both VCGs and individuals examined. Thus, labor requirements limit use of VCA and relatively few Aspergillus section Flavi population studies report VCG diversity (Atehnkeng et al. 2016; Barros et al. 2006; Bayman and Cotty 1991b; Horn and Greene 1995; Horn et al. 1996; Houshyar-Fard et al. 2014; Mauro et al. 2013; Novas and Cabral 2002; Pildain et al. 2004; Probst et al. 2011; Sweany et al. 2011). During VCA, nit mutants are generated for all isolates. Mutants are classified as $c n x$, niaD, or nirA- based on phenotypes on chemically defined phenotyping media (Cove 1976). Complementary cnx and niaD mutants (called a tester pair) are used to define a VCG. Formation of prototrophic growth in the zone of hyphal interaction between a nit mutant and the cnx or niaD mutants indicates membership in the VCG defined by that tester pair (Bayman and Cotty 1991b). When a cnx mutant cannot be selected, tester pairs may be composed of niaD and nirA $A^{-}$mutants, although successful complementation may be less reliable (Bayman and Cotty 1991a; Correll et al. 1987).

The dominance of the L morphotype in Aspergillus communities associated with many crops (Cardwell and Cotty 2002; Cotty 1997; Doster and Michailides 1994a; Doster et al. 1996; Mauro et al. 2013), the great variability in aflatoxin-producing ability among L morphotype VCGs (Bayman and Cotty 1993; Cotty et al. 1994), and the use of $\mathrm{L}$ morphotype isolates as biocontrol agents for the prevention of aflatoxin contamination (Alaniz Zanon et al. 2013; Bandyopadhyay et al. 2016; Cotty et al. 2007; Mauro et al. 2015) encouraged us to investigate the dynamics of A. flavus L morphotype community composition in Sonora with VCA. VCA allow successes of lineages to be monitored over space and time. Assessment of aflatoxinproducing potentials of individuals within a VCG allows identification of aflatoxin-producing or atoxigenic VCGs and may facilitate design of aflatoxin management programs. Whether intrinsic characteristics of an AES influence compositions of communities of A. flavus $\mathrm{L}$ morphotype VCGs is unknown. VCG diversity within AES needs to be contrasted with diversity among AES, and VCG diversity within years needs to be contrasted with diversity among years. The current study sought to utilize VCA to evaluate AES influences on A. flavus community composition and to assess the extents to which both community composition and diversity vary across years. These questions were addressed by contrasting communities of the A. flavus L morphotype resident in soil cropped to maize in four AES of Sonora, Mexico, across 3 years. The results indicate that compositions of A. flavus communities associated with maize production in Sonora, Mexico, are similar among AES but fluctuate significantly across years, with dominant VCGs varying over time.

\section{MATERIALS AND METHODS}

Fungi. Genetic diversity within communities of A. flavus $\mathrm{L}$ morphotype was examined among 869 isolates recovered from 83 maize field soils collected during summer 2006 (387 isolates from 27 soil samples collected in July), summer 2007 (240 isolates from 26 soil samples collected in July), and summer 2008 (242 isolates from 30 soil samples collected in June) in Sonora, Mexico (Table 1). Seventy-three percent of the examined soils were sampled during each of the 3 years. Number of samples among and within AES differed among years due to either absence of maize production along the planed sampling route or inaccessibility as a result of flooding or security-compromised areas. Briefly, georeferenced soil samples were collected from fields previously cultivated with maize in four AES (Table 1; Fig. 1). These AES - Alamos (AL), Tesopaco (TE), Yaqui Valley (YV), and Yecora (YE) - differ in elevation, temperature, precipitation, and irrigation practice. In YV, the AES at the lowest elevation, approximately 40 crops are planted annually on more than 200,000 ha totally dependent on irrigation (Lobell et al. 2003; SIACON 2010). Crop production in the other three AES occur on fewer hectares and all planted crops are rainfall dependent (SIACON 2010; Vásquez-León and Liverman 2004; Vásquez-León et al. 2003). Maize fields were distributed across approximately $200 \mathrm{~km}$ at elevations ranging from 6 to 2,100 MASL. Fields $>20$ ha were sampled in YV, whereas small fields of $<5$ ha were sampled in the other AES.

The examined fungi were part of a previous study (OrtegaBeltran et al. 2015) and were obtained from soils by dilution plate technique on modified rose Bengal agar (Cotty 1994a). During that study, the recovered fungi included both morphotypes of A. flavus, A. parasiticus, $A$. tamarii, and an unknown taxon. In the current study, in order to assess both diversity within the A. flavus L morphotype and impacts of diversity on aflatoxin-producing potentials of Aspergillus communities in Sonora, A. flavus L morphotype isolates were subjected to VCA.

Assignment of isolates to VCG. The nit mutants of the 869 A. flavus $\mathrm{L}$ morphotype isolates were selected on SEL agar (Czapek-Dox broth with $25 \mathrm{~g}$ of $\mathrm{KClO}_{3}, 50 \mathrm{mg}$ of rose Bengal, and $2 \%$ Bacto agar [Difco Laboratories, Detroit] per liter, pH 7.0) (Cotty $1994 b$ ) by seeding spore suspensions (approximately 1,000 spores in $15 \mu \mathrm{l}$ ) into 3 -mm central wells cut into agar. Plates were incubated for up to 30 days $\left(31^{\circ} \mathrm{C}\right.$ in darkness). Spontaneous auxotrophic sectors were transferred onto MIT agar (Czapek-Dox broth with $15 \mathrm{~g}$ of $\mathrm{KClO}_{3}$ and $2 \%$ Bacto agar per liter, $\mathrm{pH}$ 6.5) (Das et al. 2008), and incubated for 3 days $\left(31^{\circ} \mathrm{C}\right.$ in darkness) to purify mutants of residual wild-type mycelia. Mutants were then grown on 5-2 agar (5\% V8 Juice [Campbell Soup Company, Camden, NJ] and 2\% Bacto agar, $\mathrm{pH}$ 6.0) for 7 days $\left(31^{\circ} \mathrm{C}\right.$ in darkness). After incubation, nit mutants were stored and maintained as previously described (Probst et al. 2011)

Tester pairs of VCGs were developed by pairing of an niaD mutant with either a cnx or nirA- mutant on starch agar (SA) (36 g of dextrose, $20 \mathrm{~g}$ of soluble starch, $3 \mathrm{~g}$ of $\mathrm{NaNO}_{3}$, and $2 \%$ Bacto agar per liter, $\mathrm{pH}$ 6.0) (Cotty and Taylor 2003). Complementary pairs were used to define individual VCGs. Fungal suspensions (approximately 1,000 spores in $15 \mu \mathrm{l}$ ) of the two testers and the nit mutant from the isolate being evaluated for membership in the VCG were seeded

TABLE 1. Four agroecosystems (AES) of Sonora, Mexico sampled from 2006 to 2008

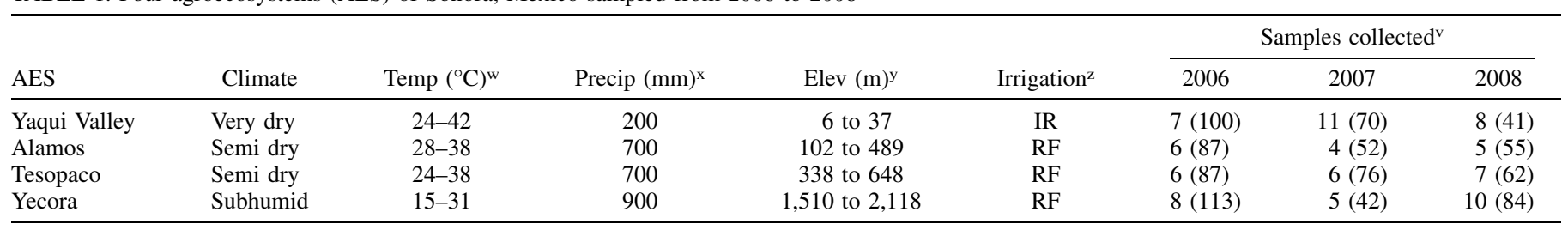

${ }^{v}$ Number of samples was dependent on the availability of maize fields at the time of sampling across the AES. Numbers in parenthesis correspond to the Aspergillus flavus L morphotype isolates recovered and characterized into vegetative compatibility groups from each AES during each year.

${ }^{\text {w }}$ Temperature maxima range.

${ }^{x}$ Approximate annual precipitation.

y Elevation of sampling locations (meters above sea level).

${ }^{\mathrm{z}} \mathrm{IR}=$ irrigated land and $\mathrm{RF}=$ rain-fed land. 
individually into one of three 3-mm wells spaced $1 \mathrm{~cm}$ apart in a triangular pattern on SA and incubated for 7 days $\left(31^{\circ} \mathrm{C}\right.$ in darkness). Complementary isolates were placed in the VCG defined by that tester pair. Tester pairs were generated and complementations performed until each isolate was assigned into a VCG. In a similar manner, isolates were also tested for membership in YV36, the VCG to which the biocontrol agent AF36 belongs, utilizing previously described testers ATCC 96045 and ATCC 96047 (Cotty 1994b).

Diversity indices. Simpson's diversity index $(D)$ was calculated for A. flavus L morphotype VCGs in single and multiple years for both individual and combined AES by assessing proportions of the total A. flavus $\mathrm{L}$ morphotype population composed by each VCG: $D=1 / \sum_{i=1}^{S} P i^{2}$, where $P i$ is the proportion for the $i$ th VCG and $S$ is the total number of VCGs in the population (VCG richness). Equitability $(E)$ was obtained by calculating the proportion of the maximum possible value of $D\left(D_{\max }=S\right)$, assuming even distribution of isolates among VCGs: $E=D / S$. $E$ assumes values between 0 and 1 . The closer $E$ gets to 1 , the more equitable is the population (Begon et al. 1996). $D$ increases with equitability for a given richness and increases with richness for a given equitability.

Shannon-Wiener diversity index $(H)$ was calculated for single and combined years for both individual and combined AES with $P i$ values: $H=-\sum_{i=1}^{S} P i^{*} \ln P i$. Equitability $(J)$ was calculated as $H / \ln S$. $J$ assumes values between 0 and 1 (Begon et al. 1996).

A simple diversity index was calculated by dividing the number of isolates with the number of VCGs in single and multiple years for both individual and combined AES, as described by Horn and Greene (1995). Equitability for simple diversity was not calculated.

Isolate ability to produce aflatoxins. Aflatoxin-producing ability of each of the 387 A. flavus L morphotype isolates recovered from 2006 was assessed in a previous study (Ortega-Beltran et al. 2015).

Statistical analyses. All statistical analyses were conducted with SAS 9.2 (SAS Institute Inc., Cary, NC). VCG frequencies, diversity indices, and equitability among (same year) and within (across years) AES were summarized and analyzed with the general linear model procedure. Means of frequent VCGs were separated with Fisher's least significant difference test $(\alpha=0.05)$; means of VCG SON001 across years were analyzed with the Kruskal-Wallis test because variances were unequal. Significant differences were detected and means were separated with Dunn's multiple comparison procedure. Means of diversity indices and equitability for both Simpson's and Shannon-Wiener's methods were standardized by

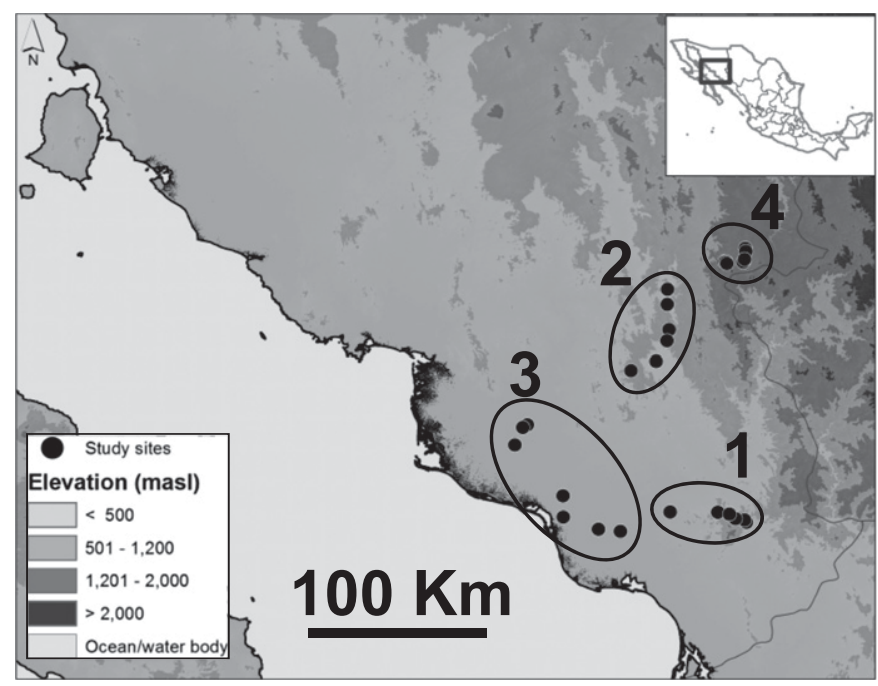

Fig. 1. Approximate location of collection sites of fields cropped to maize in four agroecosystems of Sonora, Alamos (1), Tesopaco (2), Yaqui Valley (3), and Yecora (4), from which populations of Aspergillus section Flavi were sampled from 2006 to 2008. dividing each value by the overall mean of the corresponding statistic. Pearson correlations of dominant VCGs between years for individual AES and the combined four AES were conducted using the CORR Procedure of SAS $(\alpha=0.05)$.

\section{RESULTS}

Association of A. flavus VCGs with maize soils. In a previous study, 869 A. flavus L morphotype isolates were recovered from 83 maize field soil samples collected from 2006 to 2008 (Ortega-Beltran et al. 2015). In the current study, those 869 isolates were assigned into 136 VCGs. The number of VCGs differed significantly in each of the 3 years. In 2007 and 2008, greater than five times more VCGs were detected than during 2006, even though more isolates were examined in 2006 (Table 2). This resulted in a simple diversity index equal to $0.03,0.37$, and 0.34 for 2006,2007 , and 2008 , respectively. VCGs for which only a single member was detected ranged from 21 to $48 \%$ annually (Table 2). VCGs were grouped in five ranges based on the number of members: (i) 1 , (ii) 2 to 4 , (iii) 5 to 10 , (iv) 11 to 20 , and (v) $>20$ members (Table 3 ). The great majority of VCGs (79\%) were composed of fewer than five members. More than $66 \%$ of the VCGs were found only during a single year. All VCGs composed of $>20$ members were detected in multiple years. In all, 87 VCGs $(64 \%)$ were detected only in a single AES. Forty-four VCGs (32\%) were found in more than 1 year, with 12 VCGs (9\%) occurring in all 3 years (Table 3 ). All 12 VCGs detected in all 3 years were found in at least two AES and 8 of these VCGs $(6 \%)$ were detected in all four AES (Table 3). Only 10 dominant VCGs (7\%) occurred in all four AES (two of the VCGs occurring in all AES were not counted as dominant because their frequencies did not exceed $1 \%$ ).

VCGs that made up $>1 \%$ of the L morphotype population (14 total) across the 3 years were considered dominant (Table 4). Frequencies of the dominant VCGs fluctuated over time, with seven of them differing significantly $(P<0.05)$ among years (Table 4$)$. For example, SON003 in 2006 was the sole VCG detected in all sampled fields during any single year when it composed more than $75 \%$ of the L morphotype population. However, SON003 was only detected in six fields across the four AES during 2007 and in two fields in only one AES in 2008, when it composed $<1 \%$ of the overall population. Similarly, the second most dominant VCG in 2006, SON001, detected in 22 fields, was not detected during 2007, and only two isolates, each from a separate AES, were detected in 2008.

VCGs SON004, SON007, SON008, SON050, and SON122 were detected in low frequencies in either one or two AES during 2006 but were more common during 2007 and/or 2008. VCG SON034 was ninefold more common in 2008 than in $2007(P<0.05)$ but was not detected in 2006. VCG SON024 was the sole dominant VCG detected in only a single year (2008); however, SON024 frequencies were not significantly $(P=0.2855)$ different across years. Frequencies of dominant VCGs during 1 year were not correlated with frequencies in other years when examining individual AES or the

TABLE 2. Aspergillus flavus L morphotype isolates and vegetative compatibility groups (VCGs) detected in four agroecosystems (AES) of Sonora, Mexico

\begin{tabular}{lccc}
\hline & \multicolumn{3}{c}{ Year } \\
\cline { 2 - 4 } Variable & 2006 & 2007 & 2008 \\
\hline Isolates $^{\mathrm{x}}$ & $387(0.95)$ & $240(0.38)$ & $242(0.47)$ \\
Total VCGs $^{\mathrm{y}}$ & $15(1)$ & $91(46)$ & $84(41)$ \\
${\text { VCGs with only } 1 \text { member }^{\mathrm{z}}}$ & 4 & 44 & 18 \\
\hline
\end{tabular}

${ }^{\mathrm{x}}$ A. flavus $\mathrm{L}$ morphotype isolates collected in the four AES. Numbers in parenthesis correspond to proportions of the $\mathrm{L}$ morphotype within the Aspergillus section Flavi population during the indicated year.

y Number of A. flavus L morphotype VCGs detected in each year across the four AES. Italicized numbers in parenthesis correspond to VCGs found solely during that year.

z VCGs detected once during the indicated year. 
combined four AES (Table 5). Representative examples of variation in incidences of VCGs among AES and across years are given in Figure 2. In all cases, relatively high VCG frequencies were detected only during a single year and, sometimes, only in a single AES.

VCG YV36, to which the atoxigenic biocontrol agent Aspergillus flavus AF36 belongs (Cotty et al. 2007; Ehrlich and Cotty 2004), was detected all 3 years in each AES, with no significant differences in frequencies across years. AF36 has not been applied to maize or any other crop in the examined AES. Indeed, there is no registration for AF36 use in Mexico. The detected YV36 isolates from Sonora belong to a fairly common YV36 population endemic to Mexico (Ortega-Beltran et al. 2016).

Aflatoxin-producing ability. In a previous study, $95 \%$ of the A. flavus L morphotype isolates from 2006 produced aflatoxin

TABLE 3. Detection of Aspergillus flavus L morphotype vegetative compatibility groups (VCGs) in four agroecosystems (AES) of Sonora, Mexico

\begin{tabular}{|c|c|c|c|c|c|c|c|c|c|c|c|c|c|c|c|c|}
\hline \multirow[b]{3}{*}{$\mathrm{FG}^{\mathrm{x}}$} & \multicolumn{5}{|c|}{ Single yearw } & \multicolumn{5}{|c|}{ Two years ${ }^{w}$} & \multicolumn{5}{|c|}{3 years $^{w}$} & \multirow[b]{3}{*}{ Total VCGs ${ }^{y}$} \\
\hline & \multirow[b]{2}{*}{ VCG } & \multicolumn{4}{|c|}{ AES } & \multirow[b]{2}{*}{ VCG } & \multicolumn{4}{|c|}{ AES } & \multirow[b]{2}{*}{ VCG } & \multicolumn{4}{|c|}{ AES } & \\
\hline & & 1 & 2 & 3 & 4 & & 1 & 2 & 3 & 4 & & 1 & 2 & 3 & 4 & \\
\hline 1 (rare) & 52 & 52 & NA & NA & NA & NA & NA & NA & NA & NA & NA & NA & NA & NA & NA & 52 \\
\hline $2-4$ & 34 & 27 & 7 & 0 & 0 & 20 & 6 & 11 & 3 & 0 & 1 & 0 & 1 & 0 & 0 & 55 \\
\hline $5-10$ & 3 & 2 & 0 & 1 & 0 & 8 & 0 & 3 & 5 & 0 & 4 & 0 & 1 & 2 & 1 & 15 \\
\hline $11-19$ & 1 & 0 & 1 & 0 & 0 & 4 & 0 & 2 & 2 & 0 & 1 & 0 & 0 & 0 & 1 & 6 \\
\hline$>20$ (common) & 0 & 0 & 0 & 0 & 0 & 2 & 0 & 0 & 0 & 2 & 6 & 0 & 0 & 0 & 6 & 8 \\
\hline Total VCGs ${ }^{\mathrm{z}}$ & 90 & $\ldots$ & $\ldots$ & $\ldots$ & $\ldots$ & 34 & $\ldots$ & $\ldots$ & $\ldots$ & $\ldots$ & 12 & $\ldots$ & $\ldots$ & $\ldots$ & $\ldots$ & 136 \\
\hline
\end{tabular}

w Number of VCGs detected during either a single year, 2 years, or 3 years. Number of VCGs per classification and the number of AES in which VCGs were detected is indicated. For example, for VCGs composed of 2 to 4 members and detected during a single year (34 total), 27 VCGs were detected in a single AES while 7 VCGs were detected in two AES. NA indicates not applicable, for examples, VCGs with 1 member, can only be detected in 1 AES, and only in 1 year. Bold numbers indicate where VCGs were detected.

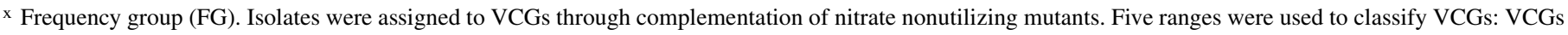
with (i) 1, (ii) 2 to 4 , (iii) 5 to 10 , (iv) 10 to 20, and (v) $>20$ members.

y Number of VCGs within each FG summed across the 3 years.

z Sum of VCGs detected during 1,2 , or 3 years.

TABLE 4. Frequencies (percentages) of vegetative compatibility groups (VCGs) that composed more than $1 \%$ of the entire Aspergillus flavus $\mathrm{L}$ morphotype population in four agroecosystems (AES) of Sonora, Mexico over a 3-year period ${ }^{\mathrm{w}}$

\begin{tabular}{|c|c|c|c|c|c|c|c|c|c|c|c|c|c|c|c|c|c|c|c|}
\hline \multirow[b]{3}{*}{$\mathrm{VCG}^{\mathrm{x}}$} & \multicolumn{6}{|c|}{2006} & \multicolumn{6}{|c|}{2007} & \multicolumn{6}{|c|}{2008} & \multirow[b]{3}{*}{ Across years } \\
\hline & \multicolumn{4}{|c|}{ AES } & \multirow[b]{2}{*}{ Mean } & \multirow[b]{2}{*}{ Loc } & \multicolumn{4}{|c|}{ AES } & \multirow[b]{2}{*}{ Mean } & \multirow[b]{2}{*}{ Loc } & \multicolumn{4}{|c|}{ AES } & \multirow[b]{2}{*}{ Mean } & \multirow[b]{2}{*}{ Loc } & \\
\hline & $\mathrm{YV}$ & $\mathrm{AL}$ & $\mathrm{TE}$ & YE & & & YV & $\mathrm{AL}$ & $\mathrm{TE}$ & $\mathrm{YE}$ & & & YV & $\mathrm{AL}$ & $\mathrm{TE}$ & YE & & & \\
\hline SON003 & 17.8 & 17.1 & 16.5 & 24.0 & $19.5 \mathrm{a}$ & 27 & 1.7 & 0.8 & 0.4 & 0.4 & $1.4 \mathrm{a}-\mathrm{e}$ & 6 & 0 & 0 & 1.7 & 0 & $0.7 \mathrm{~b}$ & 2 & $\mathrm{~A}, \mathrm{~B}, \mathrm{~B} * * *$ \\
\hline SON004 & 0.5 & 0 & 0 & 0.5 & $0.3 \mathrm{c}$ & 2 & 1.3 & 0.4 & 0.8 & 0.4 & $1.2 \mathrm{~b}-\mathrm{e}$ & 6 & 0.4 & 0.4 & 2.9 & 0.4 & $1.7 \mathrm{ab}$ & 7 & $\mathrm{~A}, \mathrm{~A}, \mathrm{~A}$ \\
\hline SON006 & 0.8 & 0.5 & 1.6 & 0.3 & $0.8 \mathrm{c}$ & 8 & 0 & 0 & 0.4 & 0 & $0.2 \mathrm{de}$ & 1 & 0 & 0 & 0 & 0.4 & $0.2 \mathrm{~b}$ & 1 & $\mathrm{~A}, \mathrm{~B}, \mathrm{~B} *$ \\
\hline SON007 & 1.3 & 0 & 0 & 0 & $0.3 \mathrm{c}$ & 1 & 1.7 & 0.4 & 3.3 & 0.4 & $2.4 \mathrm{a}-\mathrm{c}$ & 8 & 0.4 & 0 & 0 & 0.4 & $0.3 \mathrm{~b}$ & 2 & $\mathrm{~A}, \mathrm{~A}, \mathrm{~A}$ \\
\hline SON026 & 0 & 0 & 0 & 0 & $0 \mathrm{c}$ & 0 & 1.7 & 0 & 0.8 & 0 & $1.0 \mathrm{c}-\mathrm{e}$ & 6 & 0 & 6.6 & 0 & 3.7 & $4.3 \mathrm{ab}$ & 6 & $\mathrm{~A}, \mathrm{~A}, \mathrm{~A}$ \\
\hline SON027 & 0 & 0 & 0 & 0 & $0 \mathrm{c}$ & 0 & 1.3 & 0 & 0.8 & 0.4 & $1.0 \mathrm{c}-\mathrm{e}$ & 6 & 0 & 0 & 4.1 & 0.8 & $2.0 \mathrm{ab}$ & 4 & $\mathrm{~A}, \mathrm{~A}, \mathrm{~A}$ \\
\hline SON034 & 0 & 0 & 0 & 0 & $0 \mathrm{c}$ & 0 & 0 & 0.8 & 0 & 0 & $0.3 \mathrm{de}$ & 2 & 0.8 & 2.5 & 2.1 & 1.7 & $2.9 \mathrm{ab}$ & 8 & $\mathrm{~B}, \mathrm{~B}, \mathrm{~A}^{*}$ \\
\hline SON040 & 0 & 0 & 0 & 0 & $0 \mathrm{c}$ & 0 & 0.8 & 0 & 2.1 & 1.7 & $1.9 \mathrm{a}-\mathrm{d}$ & 6 & 0.8 & 0 & 0.4 & 0 & $0.5 \mathrm{~b}$ & 2 & $\mathrm{~B}, \mathrm{~A}, \mathrm{AB}$ \\
\hline SON050 & 0 & 0 & 0 & 0 & $0 \mathrm{c}$ & 0 & 0.8 & 1.7 & 0.8 & 0.4 & $1.6 \mathrm{a}-\mathrm{e}$ & 6 & 0 & 0 & 0.8 & 0 & $0.3 \mathrm{~b}$ & 1 & $\mathrm{~B}, \mathrm{~A}, \mathrm{~B} *$ \\
\hline SON122 & 0.3 & 0 & 0 & 0 & $0.1 \mathrm{c}$ & 0 & 0.8 & 3.8 & 1.7 & 1.3 & $3.1 \mathrm{a}$ & 11 & 1.2 & 0.4 & 0 & 1.2 & $1.2 \mathrm{ab}$ & 7 & $\mathrm{~B}, \mathrm{~A}, \mathrm{AB} *$ \\
\hline YV36 & 0.3 & 0.5 & 0.3 & 0.3 & $0.3 \mathrm{c}$ & 5 & 0.4 & 0 & 1.3 & 0 & $0.7 \mathrm{c}-\mathrm{e}$ & 3 & 0 & 0 & 0 & 5.0 & $1.2 \mathrm{ab}$ & 1 & $\mathrm{~A}, \mathrm{~A}, \mathrm{~A}$ \\
\hline
\end{tabular}

${ }^{\mathrm{w}}$ Percentage of the total population (869 isolates) composed of each VCG in each AES: YV = Yaqui Valley, AL = Alamos, TE $=$ Tesopaco, and YE $=$ Yecora. Mean $=$ average VCG frequency across the four AES. Values correspond to the average incidence during the 3 years. VCG means with the same lowercase letters are not significantly different by Fisher's protected least significant difference (LSD) test $(\alpha=0.05)$. Loc $=$ number of locations in which each VCG was detected. ${ }^{x}$ Code used to identify VCGs in Sonora. The listed VCGs composed more than $1 \%$ of the A. flavus L morphotype population during the 3 years of the study. Frequencies were determined by assigning 869 isolates recovered across 3 years in four AES to VCGs with analyses based on nitrate-nonutilizing mutants.

y Separation of means among years based on Fisher's protected LSD test $(\alpha=0.05)$, except for SON001, where Kruskal-Wallis test and Dunn's multiple comparison $(\alpha=0.05)$ were used due to unequal variances. First, second, and third uppercase letters correspond to VCG frequencies during 2006, 2007, and 2008, respectively. A single asterisk indicates $P<0.05$. Triple asterisks indicate $P<0.0001$.

${ }^{z} P$ value of mean separation of frequencies of VCGs in single years based on Fisher's protected LSD test $(\alpha=0.05)$.

TABLE 5. Pearson correlation coefficients for the comparison of frequencies of dominant vegetative compatibility groups between years for individual and combined agroecosystems (AES)

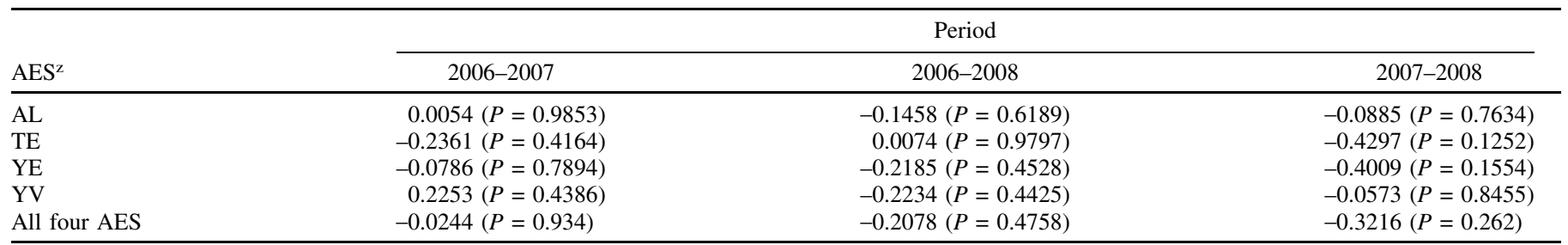

$\mathrm{z}$ AL $=$ Alamos, $\mathrm{TE}=$ Tesopaco, $\mathrm{YE}=$ Yecora, and $\mathrm{YV}=$ Yaqui Valley. 
$\mathrm{B}_{1}$ (range $=45$ to $24,000 \mathrm{ng} / \mathrm{g}$ of mycelium weight) in liquid fermentation (Ortega-Beltran et al. 2015). In the current study, aflatoxin-producing potential was associated with VCG grouping. Seventeen isolates did not produce detectable amounts of aflatoxins and these were recovered from all AES, with five each in YV and $\mathrm{TE}$, four in YE, and three in AL. The atoxigenic isolates belonged to eight VCGs (data not shown). Only two of these VCGs contained exclusively atoxigenic members, one of them being YV36 (OrtegaBeltran et al. 2016). Six of the dominant VCGs (Table 4) contained at least one atoxigenic isolate (data not shown), including one isolate belonging to SON003, the most dominant VCG during 2006.

Diversity indices. In each year, VCG diversities did not differ $(P<0.05)$ among AES but diversity within each AES and the combined AES differed significantly between years. Diversity results were similar with each of the three diversity indices. Therefore, only values for Simpson's diversity index are presented in Table 6. Equitability results were also similar for Simpson's and ShannonWiener and only the results from the former are presented. Less $(P<$ $0.001)$ diversity was detected in the examined populations during 2006 than in either 2007 or 2008 (Table 6). Simpson's diversity indices were greater in both 2007 and 2008 than in 2006 both within each AES and for the combined four AES (Table 7). When analyzing VCG diversity indices in all possible combinations of 2 years, similar diversity was detected both within each AES and for the combined four AES (Table 7). However, diversity was higher when the data from all 3 years were combined than it was for any 2 years combined. The greatest diversity was detected when only a single year or a single AES was examined (Table 7).

\section{DISCUSSION}

In Mexico, maize is cultivated regardless of elevation, soil type, rainfall, and AES (INEGI 1988; Plasencia 2004; SIACON 2010). The state of Sonora, located in northwest Mexico, has AES representative of Mexico's maize-producing environments over relatively short distances (Ortega-Beltran et al. 2015). Thus, Sonora is an excellent location to study influences of AES on population dynamics of aflatoxin-producing fungi associated with maize. The current study examined genetic variability exclusively within the A. flavus L morphotype resident in maize field soils of four AES in Sonora (Table 1). We prioritized the analysis on the L morphotype because (i) this morphotype dominates aflatoxin-producing fungal communities associated with many crops, including maize (Cardwell and Cotty 2002; Cotty 1997; Donner et al. 2009; Doster and Michailides 1994a; Horn and Dorner 1999; Mauro et al. 2013; Ortega-Beltran et al. 2015); (ii) aflatoxin-producing ability varies greatly among L morphotype VCGs (Bayman and Cotty 1993; Cotty et al. 1994); and (iii) atoxigenicity in L morphotype VCGs is a trait exploited to prevent crop aflatoxin contamination (Alaniz Zanon et al. 2013; Atehnkeng et al. 2014; Bandyopadhyay et al. 2016; Cotty et al. 2007; Dorner 2009; Mauro et al. 2015; Mehl et al. 2012). Genetic diversity was assessed within the A. flavus L morphotype by assigning all 869 isolates recovered during the course of 3 years into VCGs by employing nit mutants on VCA (Bayman and Cotty 1991a). This allowed comparison with previous, less-extensive efforts to detect shifts in aflatoxin-producing fungal genotypes (Barros et al. 2006; Bayman and Cotty 1991b, 1993; Horn and Greene 1995; Mauro et al. 2013; Novas and Cabral 2002; Pildain et al. 2004; Sweany et al. 2011) and studies examining genetic diversity among atoxigenic genotypes (Atehnkeng et al. 2016; Horn and Dorner 1999; Probst et al. 2011).

VCA were conducted immediately after nit mutant recovery by testing for membership in VCG YV36. Interest in investigating frequencies of this VCG stems from use of AF36 as the active ingredient in the first biopesticide registered by the U.S. Environmental Protection Agency for use in mitigation of aflatoxin contamination. AF36 continues to be used in cotton, maize, and pistachio (Cotty et al. 2007; Doster et al. 2014). YV36 frequencies span over large portions of the United States, including the Sonoran Desert (Cotty 1989, 1997; Grubisha and Cotty 2015). Sonora and Arizona share over 350 miles of border and large portions of these states belong to the Sonoran Desert (Ricketts et al. 1999), a region in which aflatoxin-producing fungi are ubiquitous in both agricultural and noncultivated areas (Boyd and Cotty 2001; Cotty 1989).
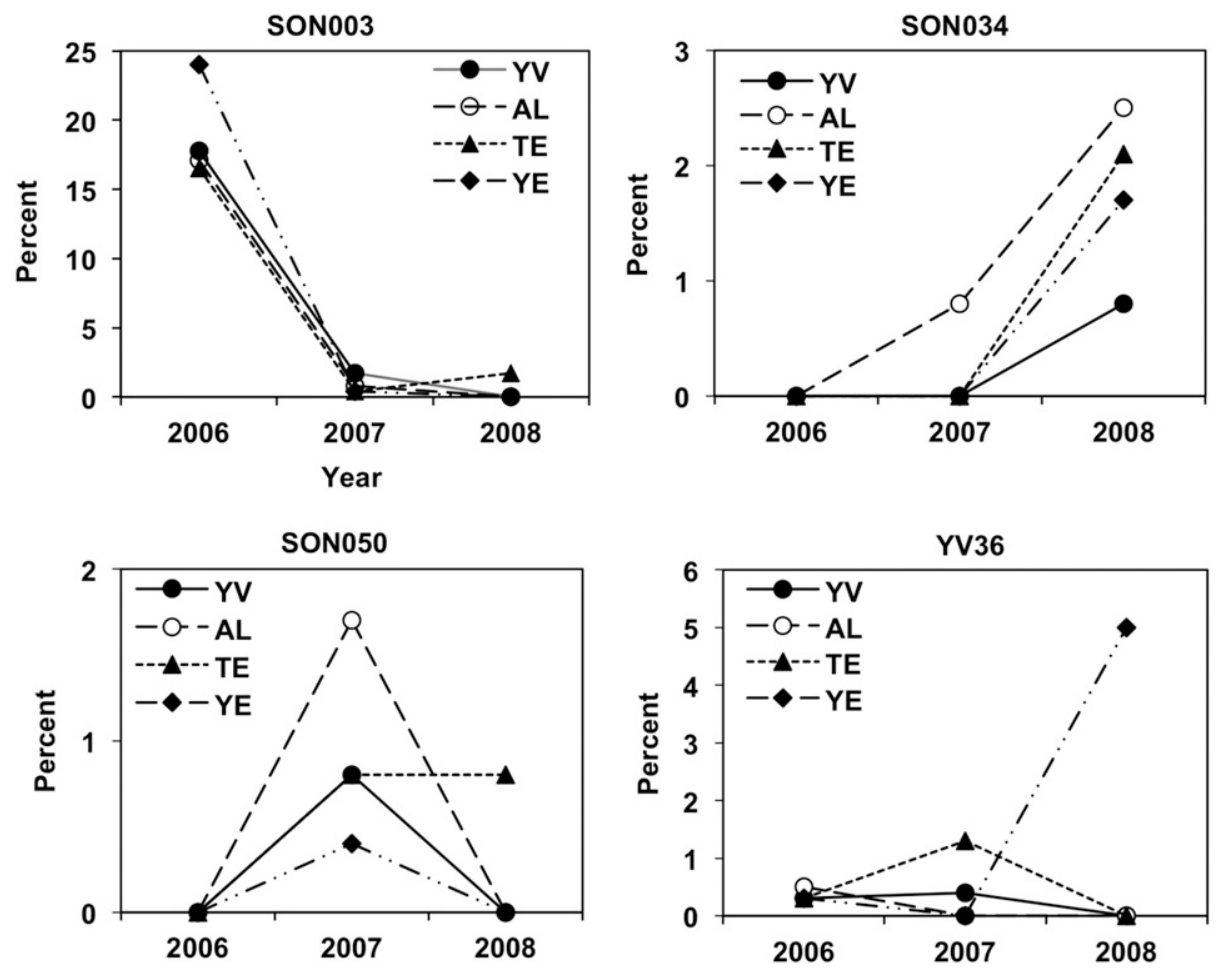

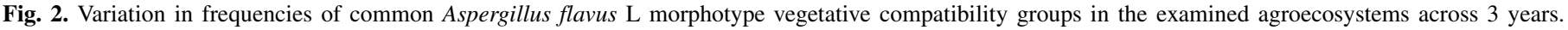
$\mathrm{YV}=$ Yaqui Valley, $\mathrm{AL}=$ Alamos, $\mathrm{TE}=$ Tesopaco, and $\mathrm{YE}=$ Yecora. 
Detection of YV36 in maize field soils of Sonora was expected. VCG YV36 was widely distributed in Sonora (Ortega-Beltran et al. 2016) (Table 4). Approximately $1 \%$ of the L morphotype isolates were assigned to YV36. The current study is the first to address frequencies of additional VCGs in Sonora.

The L morphotype composed a greater proportion of the A.flavus population during 2006 than in either 2007 or 2008 (Ortega-Beltran et al. 2015) (Table 2). Over 35\% more isolates were recovered during 2006 compared with the other years and, thus, greater VCG diversity was expected during 2006 because genetic diversity in microorganism populations tends to increase with the number of examined individuals (Grünwald et al. 2003). However, this was not the case, and fivefold more VCGs were detected in 2007 and 2008 than in 2006 (Table 2). The number of VCGs detected during 2006

TABLE 6. Variability in Aspergillus flavus L morphotype vegetative compatibility groups (VCG) diversity among four agroecosystems (AES) of Sonora, Mexico

\begin{tabular}{|c|c|c|c|c|}
\hline \multirow[b]{2}{*}{$\mathrm{AES}^{\mathrm{x}}$} & \multicolumn{4}{|c|}{ Simpson's diversityw } \\
\hline & 2006 & 2007 & 2008 & Meany \\
\hline \multicolumn{5}{|l|}{ YV } \\
\hline$D$ & $2.1(0.15)$ & $24.8(1.88)$ & $29.5(2.24)$ & $1.42 \mathrm{a}$ \\
\hline E & $0.15(0.30)$ & $0.65(1.36)$ & $0.87(1.81)$ & $1.16 \mathrm{x}$ \\
\hline \multicolumn{5}{|l|}{$\mathrm{AL}$} \\
\hline$D$ & $1.6(0.12)$ & $16.7(1.27)$ & $7.4(0.56)$ & $0.65 \mathrm{a}$ \\
\hline E & $0.41(0.85)$ & $0.58(1.20)$ & $0.39(0.81)$ & $0.95 \mathrm{x}$ \\
\hline \multicolumn{5}{|l|}{ TE } \\
\hline$D$ & $1.8(0.14)$ & $25.8(1.95)$ & $15.3(1.15)$ & $1.08 \mathrm{a}$ \\
\hline$E$ & $0.22(0.47)$ & $0.63(1.31)$ & $0.48(0.99)$ & $0.92 \mathrm{x}$ \\
\hline \multicolumn{5}{|l|}{ YE } \\
\hline$D$ & $1.4(0.11)$ & $18.8(1.42)$ & $12.9(0.98)$ & $0.84 \mathrm{a}$ \\
\hline$E$ & $0.24(0.50)$ & $0.75(1.56)$ & $0.42(0.87)$ & $0.98 x$ \\
\hline Mean $D^{\mathrm{z}}$ & $0.13 \mathrm{~B}$ & $1.63 \mathrm{~A}$ & $1.24 \mathrm{~A}$ & $\ldots$ \\
\hline Mean $E^{\mathrm{z}}$ & $0.53 \mathrm{C}$ & $1.36 \mathrm{D}$ & $1.12 \mathrm{D}$ & $\ldots$ \\
\hline
\end{tabular}

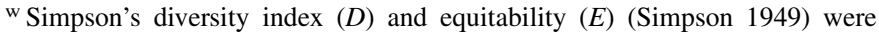
calculated each year for VCGs detected in each AES. Untransformed $D$ and $E$ values are indicated for their corresponding year in regular font (i.e., $D$ in YV during 2006 is 2.1). Numbers in parenthesis and in italics were obtained by dividing the untransformed value of $D$ by the overall mean of $D$, taking into account each AES during the 3 years, and the same criterion was used to calculate values of $E$ in italics. This was done in order to homogenize $D$ and $E$ variances among AES and within years.

${ }^{\mathrm{x}} \mathrm{YV}=$ Yaqui Valley, $\mathrm{AL}=$ Alamos, $\mathrm{TE}=$ Tesopaco, and $\mathrm{YE}=$ Yecora.

y Means of the transformed $D$ and $E$ values among AES were separated using Fisher's protected least significant difference (LSD) test $(\alpha=0.05)$. Transformed $D$ means with the same lowercase letter (a) are not significantly different. Transformed $E$ means with the same lowercase letter (x) are not significantly different.

${ }^{\text {z }}$ Means of the transformed $D$ and $E$ values across years were separated using Fisher's protected LSD test $(\alpha=0.05)$. Transformed $D$ means with the same uppercase letter (A, B) are not significantly different. Transformed $E$ means with the same uppercase letter $(C, D)$ are not significantly different.
(15 total) was apparently atypical. Studies examining diversity within aflatoxin-producing species generally report large numbers of VCGs even when examining relatively few individuals (Barros et al. 2006; Bayman and Cotty 1991b; Horn and Greene 1995; Mauro et al. 2013; Novas and Cabral 2002). Surprisingly, most VCGs detected in 2006 became either infrequent or absent in 2007 or 2008 (Tables 3 and 4). VCGs dominating communities in 2007 or 2008 were found at low frequencies in other years (limit of detection $=$ $7 \%$ within fields). This suggests that dominance of VCGs is transient (Fig. 2). This transience is detected as statistically significant variation in VCG proportions among years (Table 4).

Genotypes of A. flavus vary in sporulation during competition on crops, with incidence of certain genotypes increasing during crop production (Mehl and Cotty 2010). Results of the current study may reflect increased sporulation by highly frequent VCGs on unknown substrates and rapid dispersal of conidia over relatively large distances. Long-distance movement of fungi through atmospheric pathways occurs regularly (Isard et al. 2005). However, founder effects likely also played an important role in dictating VCG success prior to each sampling period. The current results suggest that success on one crop during one period does not guarantee subsequent dominance. Competition among genotypes is influenced by host (Mehl and Cotty 2010, 2013) and substrate but other biotic or abiotic factors may also influence compositions of aflatoxin-producing fungal communities. These influences, along with impacts of founder effects, may explain the annual shifts in A. flavus population composition observed in the current work. Certainly there are more VCGs in the region than we detected and the purpose of the current work was not to detect all VCGs in an area. Indeed, no study has been designed that could achieve this because there are likely thousands of VCGs (Bayman and Cotty 1991b; Mehl and Cotty 2010). However, the current design was sufficient to detect the most frequent VCGs in each of the sampled AES in each of the 3 years. These differences were sufficiently consistent that the preplanned statistical comparisons detected significant differences in frequencies of the major VCGs across years. This is a much more robust sampling, with more isolates better distributed in a planned manner and more sampled fields than any A. flavus VCG study previously undertaken.

In most cases, AES had no influence on frequencies of dominant VCGs, with these VCGs occurring at similar frequencies across AES (Tables 3 and 4). When the study was designed, it was anticipated that adaptive differences among VCGs would result in detection of AES-specific VCGs because A. flavus populations vary over geography (Jaime-Garcia and Cotty 2006) and are influenced by host species (Mehl and Cotty 2013) and crop rotation (JaimeGarcia and Cotty 2010). However, we detected that several VCGs increased in frequency in multiple AES in a single year (Tables 3 and 4) regardless of differences among AES in elevation, soil $\mathrm{pH}$, climate, precipitation, and cropping system (Table 1).

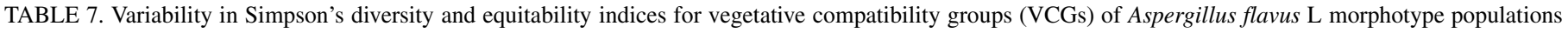
among four agroecosystems (AES) for individual and combined years

\begin{tabular}{|c|c|c|c|c|c|c|c|c|c|c|}
\hline \multirow[b]{3}{*}{ Period $^{\mathrm{z}}$} & \multicolumn{10}{|c|}{ Simpson's diversity and equitability of $\mathrm{VCGs}^{\mathrm{y}}$} \\
\hline & \multicolumn{2}{|c|}{ YV } & \multicolumn{2}{|c|}{$\mathrm{AL}$} & \multicolumn{2}{|c|}{$\mathrm{TE}$} & \multicolumn{2}{|c|}{ YE } & \multicolumn{2}{|c|}{ All AES } \\
\hline & $D$ & $E$ & $D$ & $E$ & $D$ & $E$ & $D$ & $E$ & $D$ & $E$ \\
\hline 2006 & 2.1 & 0.15 & 1.6 & 0.41 & 1.8 & 0.22 & 1.4 & 0.24 & 1.7 & 0.11 \\
\hline 2007 & 24.8 & 0.65 & 16.7 & 0.58 & 25.8 & 0.63 & 18.8 & 0.75 & 37.0 & 0.41 \\
\hline 2008 & 29.5 & 0.87 & 7.4 & 0.39 & 15.3 & 0.48 & 12.9 & 0.42 & 29.6 & 0.35 \\
\hline 2006 and 2007 & 3.4 & 0.07 & 3.3 & 0.10 & 3.1 & 0.07 & 4.6 & 0.16 & 3.9 & 0.04 \\
\hline 2006 and 2008 & 4.1 & 0.10 & 2.9 & 0.13 & 2.9 & 0.05 & 3.7 & 0.11 & 3.7 & 0.04 \\
\hline 2007 and 2008 & 3.2 & 0.05 & 2.6 & 0.06 & 3.0 & 0.05 & 2.9 & 0.06 & 3.7 & 0.03 \\
\hline All 3 years & 7.4 & 0.11 & 6.8 & 0.15 & 10.6 & 0.17 & 4.9 & 0.10 & 7.0 & 0.05 \\
\hline
\end{tabular}

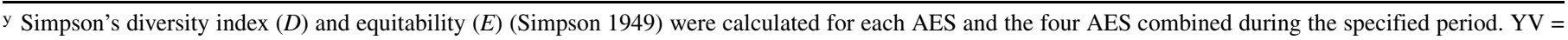

Yaqui Valley, $\mathrm{AL}=$ Alamos, $\mathrm{TE}=$ Tesopaco, and $\mathrm{YE}=$ Yecora.

z Period during which VCGs were analyzed. 
Frequencies of dominant VCGs were not correlated between years (Table 5). This was observed in each individual AES as well as in the combined four AES. Increased frequencies of a dominant VCG may have resulted from a founder event followed by rapid reproduction and dispersal rather than from superior adaptation to specific ecological pressures (Isard et al. 2005). In the short term (i.e., over the course of a season), optimal adaptation to an AES may not be a critical factor for rapid genotype increases. Adaptation may be more important for long-term (i.e., multiple years) residence of a genotype in a target AES. Greater persistence in soils (Jaime-Garcia and Cotty 2006, 2010) and organic matter (Jaime-Garcia and Cotty 2004) provides greater opportunity to participate in founder effects during subsequent crop production.

In 2006, VCG SON003 dominated every maize field soil (Table 4), with similar frequencies across AES $(P=0.5572$, data not shown). More than $75 \%$ of the $\mathrm{L}$ morphotype population of 2006 was composed of members of SON003. Other important VCGs during 2006 included SON001 and YV36, with 12 and $1 \%$ of the population, respectively (Table 4). High incidences of these three VCGs masked detection of other VCGs and, as a result, fewer VCGs were detected during 2006 in comparison with both 2007 and 2008. Similar high frequencies of an Aspergillus VCG over a large area have not been previously reported. The sole report of a VCG dominating aflatoxin-producing fungal communities in an unusual fashion was a VCG composing 55\% of the population associated with maize substrates collected from 11 fields in Mississippi (Sweany et al. 2011). Dominant VCGs in other reports have frequencies of $<25 \%$ and, commonly, $<10 \%$ (Barros et al. 2006; Bayman and Cotty 1991b; Horn and Dorner 1999; Horn and Greene 1995; Houshyar-Fard et al. 2014; Mauro et al. 2013; Novas and Cabral 2002; Pildain et al. 2004; Probst et al. 2011). However, unlike the current study, all previous studies of VCG diversity among aflatoxin-producing fungal communities assigned only a portion of the examined isolates into VCGs. In any given study, unsuccessful assignment of all recovered isolates into their corresponding VCG may skew frequencies. For example, if isolates belonging to SONO03 were not placed into a VCG, SON001 would have been the most common VCG detected in 2006.

Forces driving SON003 to dominate across diverse AES (Table 1) in 1 year and then decline in subsequent years have not been identified. Incidences of SON003 across the examined AES resembled incidences of atoxigenic $A$. flavus strains used as active ingredients in biopesticides directed at preventing aflatoxin contamination (Atehnkeng et al. 2014; Bandyopadhyay et al. 2016; Cotty et al. 2007). During the treatment year, the active ingredient VCG dominates the A. flavus community on the treated crop. In subsequent years, the atoxigenic VCG declines in frequency (Cotty and Mellon 2006). In the current study, increases and decreases in frequency were also detected for other VCGs, although at a lower magnitude than that of SONO03 (Fig. 2; Table 4). Eight of the most frequent VCGs had >20 members and were all found in all four AES; six of those VCGs were found in all 3 years (Table 3 ). High frequencies of VCGs during a given year were associated with lower frequencies during previous or subsequent years (Fig. 2). Occurrence of VCGs at high frequencies in single or multiple AES may be dictated by founder effects. This was previously observed in a cotton field in the Yuma Valley, AZ, where high frequencies of VCGs during single years were attributed to founder effects (Bayman and Cotty 1991b).

Cropping systems in YV differ greatly from those in the other AES (Ortega-Beltran et al. 2015) but such differences had little or no effect on VCG distribution (Table 4). This observation supports the notion that atoxigenic biocontrol products may be useful across multiple AES. Whether biotic or abiotic factors trigger the temporary dominance and proliferation of a VCG across contrasting AES is unknown. Mechanisms that might allow individual founder effects to influence A. flavus communities over areas as large as those observed in the current work have not been described.
A. flavus may vary in virulence, aflatoxin-producing potential, and other potentially adaptive traits (Cotty 1989; Cotty et al. 1994), and adaptive differences among VCGs may be sufficient to drive small shifts in VCG composition (Mehl and Cotty 2013; Mehl et al. 2012). However, increased frequencies of an individual VCG across several AES during a single year followed by rapid posterior decline in subsequent years cannot be explained by known adaptive differences among $A$. flavus VCGs.

VCG diversity varies with cropping system and location (Barros et al. 2006; Bayman and Cotty 1991b; Horn and Dorner 1999; Horn and Greene 1995; Horn et al. 1996; Mauro et al. 2013; Novas and Cabral 2002; Pildain et al. 2004; Probst et al. 2011; Sweany et al. 2011). However, VCG diversity is frequently examined in similar locations and/or during single years. In the current study, we examined VCG diversity across largely contrasting AES over multiple years and VCG diversity indices significantly $(P<0.05)$ differed among years (Table 6). This suggests that examining genetic diversity during a single year in either single or multiple AES has considerable limitations in estimating genetic diversity and identifying highly frequent VCGs for use as active ingredients in biopesticide formulations. Similar levels of VCG diversity were detected when examining any combination of 2 years in either a single AES or the combined four AES (Table 7). Studies examining VCG diversity should include samples collected over at least 2 years and, for more realistic estimations of VCG diversity, additional years (Table 7).

Labor requirements and other costs limit extensive examination of aflatoxin-producing genotypes in any given area. Tester pair combinations including a $c n x$ mutant are preferred because pairings of a cnx mutant with niaD mutants of the same VCG result in reliable complementation (Bayman and Cotty 1991b; Cove 1976). On average, niaD and a nirA $A^{-}$pairings result in weaker reactions and occasional failure to detect membership in a VCG (Bayman and Cotty 1991a; Correll et al. 1987; Pildain et al. 2004). In the current study, cnx mutant yields were low ( $<3 \%$ of the recovered mutants; data not shown). Low cnx frequencies increase the required labor for developing tester pairs. In all, $91 \%$ of the developed tester pairs were composed of a cnx and a niaD mutant, while the remainder was a nirA-/niaD combination. Before including a nirA- in a tester pair, more than 100 mutants of that isolate were generated, stabilized, and phenotyped without finding a cnx mutant. Development of culture media promoting increased cnx frequencies is needed in order to facilitate and encourage studies examining VCG diversity in aflatoxin-producing fungi. However, regardless of the difficulty in finding reliable tester pairs, this is the first report on A. flavus in which each isolate was assigned to a VCG. Self-incompatible isolates were not detected as in other studies on both aflatoxinproducing fungi and other species (Barros et al. 2006; Brooker et al. 1991; Correll et al. 1987, 1988, 1989; Horn and Dorner 1999; Horn and Greene 1995; Hyakumachi and Ui 1987; Mauro et al. 2013; Novas and Cabral 2002; Pildain et al. 2004).

Aflatoxin management strategies have not been developed and disseminated in Mexico even though this country has vast tropical and subtropical regions in which production of maize is at high risk of aflatoxin contamination (Cotty and Jaime-Garcia 2007; Cotty et al. 1994; Ortega-Beltran et al. 2015; Plasencia 2004; RodriguezDel-Bosque 1996). However, maize germplasm and atoxigenic fungi with the potential to decrease exposure of Mexico's population to aflatoxins are known and could be used to implement aflatoxin management (Ortega-Beltran et al. 2014; Ortega-Beltran et al. 2016). Atoxigenic VCGs detected in the current study represent genetic resources endemic to Mexico that should be considered for utilization in biocontrol programs for limiting aflatoxin contamination of maize (Cotty 2006; Mehl et al. 2012; Probst et al. 2011).

Knowledge of causes of the observed shifts in compositions of aflatoxin-producing fungal populations may lead to methods for predicting aflatoxin outbreaks (Cotty and Jaime-Garcia 2007) and allow development of practices that promote proliferation of beneficial VCGs (i.e., atoxigenic). Shifts in compositions of populations of 
aflatoxin-producing fungi should occur relatively frequently in both highly mechanized and rural agricultural areas with or without the use of atoxigenic biocontrol agents.

\section{ACKNOWLEDGMENTS}

This study was part of A. Ortega-Beltran's doctoral dissertation.

\section{LITERATURE CITED}

Alaniz Zanon, M., Chiotta, M., Giaj-Merlera, G., Barros, G., and Chulze, S. 2013. Evaluation of potential biocontrol agent for aflatoxin in Argentinean peanuts. Int. J. Food Microbiol. 162:220-225.

Amaike, S., and Keller, N. P. 2011. Aspergillus flavus. Annu. Rev. Phytopathol. 49:107-133.

Atehnkeng, J., Donner, M., Ojiambo, P. S., Ikotun, B., Augusto, J., Cotty, P. J., and Bandyopadhyay, R. 2016. Environmental distribution and genetic diversity of vegetative compatibility groups determine biocontrol strategies to mitigate aflatoxin contamination of maize by Aspergillus flavus. Microb. Biotechnol. 9:75-88.

Atehnkeng, J., Ojiambo, P., Cotty, P. J., and Bandyopadhyay, R. 2014. Field efficacy of a mixture of atoxigenic Aspergillus flavus Link: Fr vegetative compatibility groups in preventing aflatoxin contamination in maize (Zea mays L.). Biol. Control 72:62-70.

Bandyopadhyay, R., Ortega-Beltran, A., Akande, A., Mutegi, C., Atehnkeng, J., Kaptoge, L., Senghor, A. L., Adhikari, B. N., and Cotty, P. J. 2016. Biological control of aflatoxins in Africa: Current status and potential challenges in the face of climate change. World Mycotoxin J. 9:771-789.

Barros, G., Chiotta, M. L., Torres, A., and Chulze, S. 2006. Genetic diversity in Aspergillus parasiticus population from the peanut agroecosystem in Argentina. Lett. Appl. Microbiol. 42:560-566.

Battilani, P., Toscano, P., Van der Fels-Klerx, H., Moretti, A., Camardo Leggieri, M., Brera, C., Rortais, A., Goumperis, T., and Robinson, T. 2016. Aflatoxin $\mathrm{B}_{1}$ contamination in maize in Europe increases due to climate change. Sci. Rep. 6:24328.

Bayman, P., and Cotty, P. J. 1991a. Improved media for selecting nitratenonutilizing mutants in Aspergillus flavus. Mycologia 83:311-316.

Bayman, P., and Cotty, P. J. 1991b. Vegetative compatibility and genetic diversity in the Aspergillus flavus population of a single field. Can. J. Bot. 69: 1707-1711.

Bayman, P., and Cotty, P. J. 1993. Genetic diversity in Aspergillus flavus: Association with aflatoxin production and morphology. Can. J. Bot. 71: 23-31.

Begon, M., Harper, J. L., and Townsend, C. R. 1996. Ecology: Individuals, Populations, and Communities, 3rd ed. Blackwell Science Ltd., Cambridge, MA.

Binder, E. M., Tan, L. M., Chin, L. J., Handl, J., and Richard, J. 2007. Worldwide occurrence of mycotoxins in commodities, feeds and feed ingredients. Anim. Feed Sci. Technol. 137:265-282.

Boyd, M. L., and Cotty, P. J. 2001. Aspergillus flavus and aflatoxin contamination of leguminous trees of the Sonoran Desert in Arizona. Phytopathology 91:913-919.

Brooker, N. L., Leslie, J. F., and Dickman, M. N. 1991. Nitrate-nonutilizing mutants of Colletotrichum and their use in studies of vegetative compatibility and genetic relatedness. Phytopathology 81:672-677.

Cardwell, K. F., and Cotty, P. J. 2002. Distribution of Aspergillus section Flavi among field soils from the four agroecological zones of the republic of Bénin, West Africa. Plant Dis. 79:1039-1045.

Correll, J. C., Gordon, T. R., and McCain, A. H. 1988. Vegetative compatibility and pathogenicity of Verticillium albo-atrum. Phytopathology 78: 1017-1021.

Correll, J. C., Klittich, C. J. R., and Leslie, J. F. 1987. Nitrate nonutilizing mutants of Fusarium oxysporum and their use in vegetative compatibility tests. Phytopathology 77:1640-1646.

Correll, J. C., Klittich, C. J. R., and Leslie, J. F. 1989. Heterokaryon selfincompatibility in Gibberella fujikuroi (Fusarium moniliforme). Mycol. Res. 93:21-27.

Cotty, P. J. 1989. Virulence and cultural characteristics of two Aspergillus flavus strains pathogenic on cotton. Phytopathology 79:808-814

Cotty, P. J. 1994a. Comparison of four media for the isolation of Aspergillus flavus group fungi. Mycopathologia 125:157-162.

Cotty, P. J. 1994b. Influence of field application of an atoxigenic strain of Aspergillus flavus on the populations of A. flavus infecting cotton balls and on the aflatoxin content of cottonseed. Phytopathology 84:1270-1277.

Cotty, P. J. 1997. Aflatoxin-producing potential of communities of Aspergillus section Flavi from cotton producing areas in the United States. Mycol. Res. 101:698-704.
Cotty, P. J. 2006. Biocompetitive exclusion of toxigenic fungi. Pages 179-197 in: The Mycotoxin Factbook. D. Barug, D. Bhatnagar, H. P. van Egdmond, J. W. van der Kamp, W. A. van Osenbruggen and A. Visconti, eds. Wageningen Academic Publishers, The Netherlands.

Cotty, P. J., Antilla, L., and Wakelyn, P. J. 2007. Competitive exclusion of aflatoxin producers: Farmer driven research and development. Pages 241-253 in: Biological Control: A Global Perspective. C. Vincent, N. Goettel, and G. Lazarovits, eds. CAB International, Oxfordshire, UK.

Cotty, P. J., Bayman, P., Egel, D. S., and Elias, K. S. 1994. Agriculture, aflatoxins and Aspergillus. Pages 1-27 in: The Genus Aspergillus. K. Powell, ed. Plenum Press, New York.

Cotty, P. J., and Jaime-Garcia, R. 2007. Influences of climate on aflatoxinproducing fungi and aflatoxin contamination. Int. J. Food Microbiol. 119: 109-115.

Cotty, P. J., and Mellon, J. E. 2006. Ecology of aflatoxin-producing fungi and biocontrol of aflatoxin contamination. Mycotoxin Res. 22:110-117.

Cotty, P. J., and Taylor, D. R. 2003. Influence of complementation medium composition on vegetative compatibility analyses of Aspergillus flavus. (Abstr.) Phytopathology 93:S18.

Cove, D. J. 1976. Chlorate toxicity in Aspergillus nidulans: The selection and characterisaton of chlorate resistant mutants. Heredity 36:191-203.

Das, M. K., Ehrlich, K. C., and Cotty, P. J. 2008. Use of pyrosequencing to quantify incidence of a specific Aspergillus flavus strain within complex fungal communities associated with commercial cotton crops. Phytopathology 98:282-288.

Donner, M., Atehnkeng, J., Sikora, R. A., Bandyopadhyay, R., and Cotty, P. J. 2009. Distribution of Aspergillus section Flavi in soils of maize fields in three agroecological zones of Nigeria. Soil Biol. Biochem. 41:37-44.

Dorner, J. W. 2009. Biological control of aflatoxin contamination in corn using a nontoxigenic strain of Aspergillus flavus. J. Food Prot. 72:801-804

Doster, M. A., Cotty, P. J., and Michailides, T. J. 2014. Evaluation of the atoxigenic Aspergillus flavus strain AF36 in pistachio orchards. Plant Dis. 98:948-956.

Doster, M. A., and Michailides, T. J. 1994a. Aspergillus molds and aflatoxins in pistachio nuts in California. Phytopathology 84:583-590.

Doster, M. A., and Michailides, T. J. 1994b. Development of Aspergillus molds in litter from pistachio trees. Plant Dis. 78:393-397.

Doster, M. A., Michailides, T. J., and Morgan, D. P. 1996. Aspergillus species and mycotoxins in figs from California Orchards. Phytopathology 80:484-489.

Eakin, H., Bausch, J. C., and Sweeney, S. 2014. Agrarian winners of neoliberal reform: The 'Maize boom' of Sinaloa, Mexico. J. Agrar. Change 14:26-51.

Ehrlich, K. C., and Cotty, P. J. 2004. An isolate of Aspergillus flavus used to reduce aflatoxin contamination in cottonseed has a defective polyketide synthase gene. Appl. Microbiol. Biotechnol. 65:473-478.

Ehrlich, K. C., Montalbano, B. G., and Cotty, P. J. 2007. Aflatoxin-producing Aspergillus species from Thailand. Int. J. Food Microbiol. 114:153-159.

Ehrlich, K. C., Yu, J., and Cotty, P. J. 2005. Aflatoxin biosynthesis gene clusters and flanking regions. J. Appl. Microbiol. 99:518-527.

FAO. 2010. FAOSTAT. Food and Agriculture Organization, Rome. www.fao. org/faostat/.

Felger, R. S., Johnson, M. B., and Wilson, M. F. 2001. The Trees of Sonora. Oxford University Press, Oxford, UK.

Gao, J., Liu, Z., and Yu, J. 2007. Identification of Aspergillus section Flavi in maize in northeastern China. Mycopathologia 164:91-95.

Grace, D., Mahuku, G., Hoffmann, V., Atherstone, C., Upadhyaya, H. D., and Bandyopadhyay, R. 2015. International agricultural research to reduce food risks: Case studies on aflatoxins. Food Secur. 7:569-582.

Grubisha, L. C., and Cotty, P. J. 2015. Genetic analysis of the Aspergillus flavus vegetative compatibility group to which a biological control agent that limits aflatoxin contamination in USA crops belongs. Appl. Environ. Microbiol. 81:5889-5899.

Grünwald, N. J., Goodwin, S. B., Milgroom, M. G., and Fry, W. E. 2003. Analysis of genotypic diversity data for populations of microorganisms. Phytopathology 93:738-746.

Hernandez-Vargas, H., Castelino, J., Silver, M. J., Dominguez-Salas, P., Cros, M.-P., Durand, G., Le Calvez-Kelm, F., Prentice, A. M., Wild, C. P., and Moore, S. E. 2015. Exposure to aflatoxin $B_{1}$ in utero is associated with DNA methylation in white blood cells of infants in The Gambia. Int. J. Epidemiol. 44:1238-1248.

Horn, B. W., and Dorner, J. W. 1999. Regional differences in production of aflatoxin $\mathrm{B}_{1}$ and cyclopiazonic acid by soil isolates of Aspergillus flavus along a transect within the United States. Appl. Environ. Microbiol. 64:1444-1449.

Horn, B. W., and Greene, R. L. 1995. Vegetative compatibility within populations of Aspergillus flavus, A. parasiticus, and A. tamarii from a peanut field. Mycologia 87:324-332.

Horn, B. W., Greene, R. L., Sobolev, V. S., Dorner, J. W., Powell, J. H., and Layton, R. C. 1996. Association of morphology and mycotoxins production with vegetative compatibility groups in Aspergillus flavus, A. parasiticus, and A. tamarii. Mycologia 88:574-587. 
Houshyar-Fard, M., Rouhani, H., Falahati-Rastegar, M., Mahdikhani-Moghaddam, E., Malekzadeh-Shafaroudi, S., and Probst, C. 2014. Studies on Aspergillus flavus Link. isolated from maize in Iran. J. Plant Prot. Res. 54:218-224.

Hua, S.-S. T., Chang, P.-K., and Palumbo, J. 2016. Mycotoxins. Pages 153-168 in: Toxins and Other Harmful Compounds in Foods. CRC Press, Taylor \& Francis Group, Boca Raton, FL.

Hyakumachi, M., and Ui, T. 1987. Non-self-anastomosing isolates of Rhizoctonia solani obtained from fields of sugarbeet monoculture. Trans. Br. Mycol. Soc. 89:155-159.

IARC Working Group. 2002. Summary of data reported. Page 22 in: IARC Monographs on the Evaluation of Carcinogenic Risks to Humans: Some Traditional Herbal Medicines, Some Mycotoxins, Naphtalene and Styrene, Vol. 82. World Health Organization International Agency for Research on Cancer (IARC), Lyon, France.

INEGI. 1988. Atlas Nacional del Medio Físico. Instituto Nacional de Estadística, Geografía e Informática (INEGI), México, D.F.

Isard, S. A., Gage, S. H., Comtois, P., and Russo, J. M. 2005. Principles of the atmospheric pathway for invasive species applied to soybean rust. Bioscience 55:851-861.

Jaime-Garcia, R., and Cotty, P. J. 2004. Aspergillus flavus in soils and corncobs in South Texas: Implications for management of aflatoxins in corncotton rotations. Plant Dis. 88:1366-1371.

Jaime-Garcia, R., and Cotty, P. J. 2006. Spatial relationships of soil texture and crop rotation to Aspergillus flavus community structure in South Texas. Phytopathology 96:599-607.

Jaime-Garcia, R., and Cotty, P. J. 2010. Crop rotation and soil temperature influence the community structure of Aspergillus flavus in soil. Soil Biol. Biochem. 42:1842-1847.

Joffe, A. Z. 1969. Aflatoxin produced by 1,626 isolates of Aspergillus flavus from groundnut kernels and soils in Israel. Nature 221:492.

Leslie, J. F. 1993. Fungal vegetative compatibility. Annu. Rev. Phytopathol. $31: 127-150$.

Lobell, D. B., Asner, G. P., Ortiz-Monasterio, J. I., and Benning, T. L. 2003. Remote sensing of regional crop production in the Yaqui Valley, Mexico: Estimates and uncertainties. Agric. Ecosyst. Environ. 94:205-220.

Mauro, A., Battilani, P., Callicott, K. A., Giorni, P., Pietri, A., and Cotty, P. J. 2013. Structure of an Aspergillus flavus population from maize kernels in northern Italy. Int. J. Food Microbiol. 162:1-7.

Mauro, A., Battilani, P., and Cotty, P. J. 2015. Atoxigenic Aspergillus flavus endemic to Italy for biocontrol of aflatoxins in maize. BioControl 60: 125-134.

Mehl, H. L., and Cotty, P. J. 2010. Variation in competitive ability among isolates of Aspergillus flavus from different vegetative compatibility groups during maize infection. Phytopathology 100:150-159.

Mehl, H. L., and Cotty, P. J. 2013. Influence of plant host species on intraspecific competition during infection by Aspergillus flavus. Plant Pathol. 62:1310-1318

Mehl, H. L., Jaime, R., Callicott, K. A., Probst, C., Garber, N. P., Ortega-Beltran, A., Grubisha, L. C., and Cotty, P. J. 2012. Aspergillus flavus diversity on crops and in the environment can be exploited to reduce aflatoxin exposure and improve health. Ann. N. Y. Acad. Sci. 1273:7-17.

Nesci, A., and Etcheverry, M. 2002. Aspergillus section Flavi populations from field maize in Argentina. Lett. Appl. Microbiol. 34:343-348.
Novas, M. V., and Cabral, D. 2002. Association of mycotoxin and sclerotia production with compatibility groups in Aspergillus flavus from peanut in Argentina. Plant Dis. 86:215-219.

Ortega-Beltran, A., Grubisha, L. C., Callicott, K. A., and Cotty, P. J. 2016. The vegetative compatibility group to which the US biocontrol agent Aspergillus flavus AF36 belongs is also endemic to Mexico. J. Appl. Microbiol. 120: 986-998.

Ortega-Beltran, A., Guerrero-Herrera, M. D., Ortega-Corona, A., Vidal-Martinez, V. A., and Cotty, P. J. 2014. Susceptibility to aflatoxin contamination among maize landraces from Mexico. J. Food Prot. 77:1554-1562.

Ortega-Beltran, A., Jaime, R., and Cotty, P. J. 2015. Aflatoxin-producing fungi in maize field soils from sea level to over 2000 masl: A three year study in Sonora, Mexico. Fungal Biol. 119:191-200.

Papa, K. E. 1986. Heterokaryon incompatibility in Aspergillus flavus. Mycologia 78:98-101.

Pildain, M. B., Vaamonde, G., and Cabral, D. 2004. Analysis of population structure of Aspergillus flavus from peanut based on vegetative compatibility, geographic origin, mycotoxin and sclerotia production. Int. J. Food Microbiol. 93:31-40.

Plasencia, J. 2004. Aflatoxins in maize: A Mexican perspective. Toxin Rev. 23:155-177.

Probst, C., Bandyopadhyay, R., and Cotty, P. J. 2014. Diversity of aflatoxinproducing fungi and their impact on food safety in sub-Saharan Africa. Int. J. Food Microbiol. 174:113-122.

Probst, C., Bandyopadhyay, R., Price, L. E., and Cotty, P. J. 2011. Identification of atoxigenic Aspergillus flavus isolates to reduce aflatoxin contamination of maize in Kenya. Plant Dis. 95:212-218.

Probst, C., Njapau, H., and Cotty, P. J. 2007. Outbreak of an acute aflatoxicosis in Kenya in 2004: Identification of the causal agent. Appl. Environ. Microbiol. 73:2762-2764.

Probst, C., Schulthess, F., and Cotty, P. J. 2010. Impact of Aspergillus section Flavi community structure on the development of lethal levels of aflatoxins in Kenyan maize (Zea mays). J. Appl. Microbiol. 108:600-610.

Ricketts, T. H., Dinerstein, E., Olson, D. M., Loucks, C. J., Eichbaum, W., DellaSala, D. A., Kavanagh, K., Hedao, P., Hurley, P., Carney, K., Abell, R., and Walters, S. 1999. Terrestrial Ecoregions of North America: A Conservation Assessment. Island Press, Washington, DC.

Rodriguez-Del-Bosque, L. A. 1996. Impact of agronomic factors on aflatoxin contamination in preharvest field corn in northeastern Mexico. Plant Dis. 80:988-993.

SIACON. 2010. Sistema de Información Agroalimentaria de Consulta. Database of Government of Mexico. http://www.siap.gob.mx/.

Simpson, E. H. 1949. Measurement of diversity. Nature 163:688.

Sweany, R. R., Damann, K. E., Jr., and Kaller, M. D. 2011. Comparison of soil and corn kernel Aspergillus flavus populations: Evidence for niche specialization. Phytopathology 101:952-959.

Vásquez-León, M., and Liverman, D. 2004. The political ecology of land-use change: Affluent ranchers and destitute farmers in the Mexican municipio of Alamos. Hum. Organ. 63:21-33.

Vásquez-León, M., West, C. T., and Finan, T. J. 2003. A comparative assessment of climate vulnerability: Agriculture and ranching on both sides of the US-Mexico border. Glob. Environ. Change 13:159-173.

Wu, F. 2015. Global impacts of aflatoxin in maize: Trade and human health. World Mycotoxin J. 8:137-142. 